\title{
Kaolin Addition during Biomass Combustion in a 35 MW Circulating Fluidized-Bed Boiler
}

\author{
K. O. Davidsson, ${ }^{*} \dagger$ B.-M. Steenari, ${ }^{\ddagger}$ and D. Eskilsson ${ }^{\S}$ \\ Department of Energy and Environment, Energy Conversion, and Department of Chemical and Biological \\ Engineering, Environmental Inorganic Chemistry, Chalmers University of Technology, SE-412 96 \\ Göteborg, Sweden, and Technical Research Institute of Sweden, Box 857, SE-501 15 Borås, Sweden
}

Received January 29, 2007. Revised Manuscript Received May 7, 2007

\begin{abstract}
Kaolin addition to a $35 \mathrm{MW}$ circulating fluidized-bed boiler, fired with forestry residues, was performed to study the effect on bottom and fly ash. Ash samples from a period of kaolin dosage were compared with ash samples without kaolin. The samples were analyzed for elemental composition, water solubility, and mineralogical composition. The cross-section of bed particles was examined for elements. The agglomeration temperature of the material from the particle seal was determined. The kaolin, in the form of a fine powder, was supplied to the particle seal. It was found to be carried by the flue gases to the electrostatic filter rather than staying in the bed. Despite this, alkali is removed from the furnace by the kaolin, and thereby, the agglomeration temperature of the bed material increases. The alkali ends up in the fly ash, in which the content of alkali increases and the solubility of alkali decreases, suggesting that alkali aluminum silicates have been formed. These compounds have high melting points and are therefore unlikely to become liquid and stick to the surface of superheaters. A small fraction of the kaolin stays in the furnace by forming a thin layer on bed particles. It is concluded that kaolin addition can significantly enhance the operation of a fluidized bed fired with biofuels both with respect to superheater deposition and corrosion and bed agglomeration. The results show that findings in small-scale reactors are also valid in large-scale combustors. However, under the present circumstances, most kaolin ends up as fly ash.
\end{abstract}

\section{Introduction}

Heat and power generation by combustion of biomass instead of fossil fuels is advantageous for lowering carbon dioxide emissions. However, the ash components of the biomass can cause operational problems in power facilities. Such problems are bed agglomeration in fluidized beds ${ }^{1,2}$ and deposition of volatile ash components on heat-exchanger surfaces, with subsequent corrosion as a result. ${ }^{3}$ The most problematic ash constituents are the alkali metals, ${ }^{1}$ of which potassium is the most prevalent in biofuels. Generally, biomass contains 5-15 wt $\%$ potassium calculated on the ash part. ${ }^{4}$ Potassium from the inorganic part of the fuel may form silicates with low melting points on bed particle surfaces, thus rendering these surfaces sticky. ${ }^{5,6}$ It is suggested that small ash fragments from the fuel attach to the bed particle surface or that gaseous alkali compounds $\left(\mathrm{KCl}, \mathrm{KOH}, \mathrm{K}_{2} \mathrm{SO}_{4}\right.$, and $\mathrm{K}$ ) condence on or react with the surface. ${ }^{6}$ Bed particles then adhere in increasingly larger

* To whom correspondence should be addressed. E-mail: keda@ entek.chalmers.se.

$\dagger$ Department of Energy and Environment, Energy Conversion, Chalmers University of Technology.

$\doteqdot$ Department of Chemical and Biological Engineering, Environmental Inorganic Chemistry, Chalmers University of Technology.

$\S$ Technical Research Institute of Sweden.

(1) Ergudenler, A.; Gahly, A. E. Biomass Bioenergy 1993, 4, 135-147.

(2) Salour, D.; Jenkins, B. M.; Vafaei, M.; Kayhanian, M. Biomass Bioenergy 1993, 4, 117-133.

(3) Nielsen, H. P.; Frandsen, F. J.; Dam-Johansen, K.; Baxter, L. L. Prog. Energy Combust. Sci. 2000, 26, 283-298.

(4) Obernberger, I. Biomass Bioenergy 1998, 14, 33-56.

(5) Lin, W.; Dam-Johansen, K.; Frandsen, F. Chem. Eng. J. 2003, 96 , $171-185$.

(6) Öhman, M.; Nordin, A.; Skrifvars, B.-J.; Backman, R.; Hupa, M. Energy Fuels 2000, 14, 169-178. agglomerates, and eventually, this process causes defluidization and shutdown of the boiler.

Because many potassium compounds are volatile at combustion temperatures, they can be carried by the flue gas in gaseous or particulate form to various surfaces in the boiler, where they create deposits. If chlorine is present in the fuel, it is likely that potassium chloride is formed.7,8 Potassium may also form hydroxide ${ }^{9}$ or sulfate ${ }^{9,10}$ depending upon conditions in the flue gas. These volatile alkali species may condense on relatively cold surfaces, such as superheater tubes. The deposits hinder heat transfer, and components in the deposits, i.e., primarily $\mathrm{KCl}$, may facilitate corrosion. ${ }^{3,11,12}$ Finally, the tubes may have to be replaced at large costs.

One way to avoid agglomeration problems is to use a bed material other than the normal quartz-dominated sand. Such examples are olivine sand, blast-furnace slag, and diabase.

Olivine sand was shown to perform better than silica sand in a gas-heated lab-scale fluidized-bed reactor. ${ }^{13}$ Blast-furnace slag has been found to lower the agglomeration risk in a benchscale fludized bed reactor during combustion of olive residues,

(7) Baxter, L. L.; Miles, T. R., Jr.; Jenkins, B. M.; Milne, T.; Dayton, D.; Bryers, R. W.; Oden, L. L. Fuel Process. Technol. 1998, 54, 47-78. (8) Olsson, J. G.; Jäglid, U.; Pettersson, J. B. C.; Hald, P. Energy Fuels 1997, 11, 779-784.

(9) Westberg, H. M.; Byström, M.; Leckner, B. Energy Fuels 2003, 17, $18-28$.

(10) Christensen, K. A.; Stenholm, M.; Livbjerg, H. J. Aerosol Sci. 1998 $29,421-444$

(11) Pettersson, J.; Asteman, H.; Svensson, J.-E.; Johansson, L.-G. Oxid. Met. 2005, 64, 23-41.

(12) Pettersson, C.; Pettersson, J.; Asteman, H.; Svensson, J.-E.; Johansson, L.-G. Corros. Sci. 2006, 48, 1368-1378.

(13) Zintl, F. Värmeforskrapport 604, 1996. 
reed canary grass, and bark compared with quartz sand. ${ }^{14,15}$ Diabase (called Agglostop) was shown be more resistant to bed agglomeration than natural sand and feldspar during combustion of alkali-rich biofuels in a lab reactor and a commercial-scale facility. ${ }^{16}$

If potassium is captured in the bed in the form of species with high melting points, the risk of agglomeration and severe deposits can be diminished. Different additives have been suggested to achieve this. A comprehensive review of such investigations has been given. ${ }^{17}$ Examples of suggested additives are bauxite, emathlite, diatomaceous earth, kaolin (which main component is kaolinite), and calcium oxide. ${ }^{13,18-20}$ The results from these investigations have shown that kaolin is an effective absorbent for potassium under combustion conditions. Generally, kaolin has a very small particle size and thus a large specific surface area. This is beneficial for the adsorption of gaseous species from the flue gas, and it has been shown that potassium is both physically adsorbed and captured by chemical reaction. ${ }^{21-23}$ The reaction products observed when kaolin reacts with potassium are muscovite and potassium aluminum silicates, which have higher melting points than potassium silicate..$^{20,22}$

In experiments carried out in combustion conditions in a bench-scale fluidized boiler, the addition of kaolin was shown to raise the agglomeration temperature of the bed material because of depletion of potassium in the coating layer of the bed particles. ${ }^{19}$ Kaolin has also been shown to decrease chlorine deposition on superheaters. ${ }^{24,25}$ Studies of the addition of kaolin to large-scale biofuel combustion facilities are more scarce. To study deposition, the addition of kaolin was performed in a gratefired power plant and a bubbling fluidized-bed power plant. ${ }^{26}$ It was shown to decrease the amount of potassium chloride in the material deposited on test tubes in the superheater. In addition, the deposit was easier to remove than the corresponding deposits formed during normal operation without kaolin.

The purpose of the present work is to study the effect of kaolin on composition of both bottom ash and fly ash. To the knowledge of the authors, the addition of kaolin to a largescale biofuel combustion facility with this purpose is performed here for the first time. Kaolin was added to a $35 \mathrm{MW}$ circulating fluidized-bed heat and power plant. The composition and sintering temperature of bottom and fly ash were examined with and without the addition of kaolin.

\section{Experimental Section}

Circulating Fluidized Bed (CFB). The heat and power facility of Nässjö Affärsverk is a $26 \mathrm{MW}_{\text {th }}$ and $9 \mathrm{MW}_{\mathrm{el}} \mathrm{CFB}$ boiler. A schematic representation is shown in Figure 1. The boiler was

(14) Brus, E.; Öhman, M.; Nordin, A.; Broström, D. Energy Fuels 2004 $18,1187-1193$.

(15) Geyter, S. D.; Eriksson, M.; Öhman, M.; Nordin, A.; Boström, D.; Berg, M. Värmeforsk Service AB, Report number 920, 2005.

(16) Silvennoinen, J. Proceedings of the 17th Fluidized Bed Combustion (FBC) Conference, 2003

(17) Turn, S. Q.; Kinoshita, C. M.; Ishimura, D. M.; Zhou, J.; Hiraki, T. T.; Masutani, S. M. J. Inst. Energy 1998, 71, 163. 96.

(18) Rizeq, R. G.; Schadman, F. Chem. Eng. Commun. 1989, 81, 83-

(19) Öhman, M.; Nordin, A. Energy Fuels 2000, 14, 618-624. 76.

(20) Steenari, B.-M.; Lindqvist, O. Biomass Bioenergy 1998, 14, 67-

(21) Shadman, F.; Punjak, W. A. Thermochim. Acta 1988, 13, 141152 .

(22) Tran, K.-Q.; Steenari, B.-M.; Iisa, K.; Lindqvist, O. Energy Fuels 2004, 18, 1870-1876.

(23) Tran, K.-Q.; Iisa, K.; Steenari, B.-M.; Lindqvist, O. Fuel 2005, 84, $169-175$.

(24) Aho, M. Fuel 2001, 80, 1943-1951.

(25) Aho, M.; Silvennoinen, J. Fuel 2004, 83, 1299-1305.

(26) Engvall, K. Värmeforsk Service AB, Report number 742, 2001.

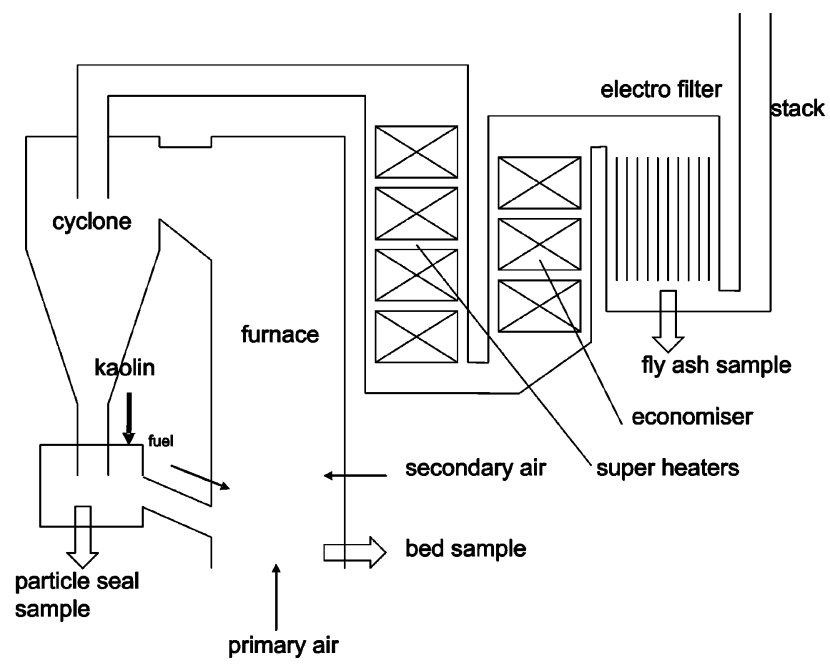

Figure 1. Schematic picture of the CFB.

Table 1. Fuel Analysis

\begin{tabular}{|c|c|}
\hline fuel analysis & wood chips \\
\hline \multicolumn{2}{|c|}{ Proximate Analysis } \\
\hline moisture as received (wt \%) & $38.06 \pm 6.47$ \\
\hline ash (wt \% dry) & $2.4 \pm 0.74$ \\
\hline \multicolumn{2}{|c|}{ Ultimate Analysis (wt \% Dry) } \\
\hline - & $51.52 \pm 1.18$ \\
\hline $\mathrm{H}$ & $6.02 \pm 0.13$ \\
\hline $\mathrm{O}$ & $39.74 \pm 1.79$ \\
\hline $\mathrm{S}$ & $0.042 \pm 0.02$ \\
\hline $\mathrm{N}$ & $0.26 \pm 0.18$ \\
\hline lower heating value $(\mathrm{MJ} / \mathrm{kg})$ & $19.24 \pm 0.40$ \\
\hline \multicolumn{2}{|c|}{ Fuel Ash Analysis (wt \% of Dry Ash) } \\
\hline $\mathrm{K}$ & $8.42 \pm 2.43$ \\
\hline $\mathrm{Na}$ & $0.87 \pm 0.35$ \\
\hline $\mathrm{Al}$ & $1.77 \pm 1.08$ \\
\hline $\mathrm{Si}$ & $9.40 \pm 4.57$ \\
\hline $\mathrm{Fe}$ & $1.05 \pm 0.72$ \\
\hline $\mathrm{Ca}$ & $22.06 \pm 5.19$ \\
\hline $\mathrm{Mg}$ & $2.46 \pm 0.22$ \\
\hline $\mathrm{P}^{\circ}$ & $1.90 \pm 0.53$ \\
\hline $\mathrm{Ti}$ & $0.14 \pm 0.09$ \\
\hline
\end{tabular}

operated at full load. The excess air ratio was $1.7-2.0$. The temperature in the bed was $810-840{ }^{\circ} \mathrm{C}$ (taken as the average of three thermocouples, of which one was situated in the center of the bottom area and the other two were situated $750 \mathrm{~mm}$ from the wall) and $870-900{ }^{\circ} \mathrm{C}$ at the top of the furnace (measured with one thermocouple situated $500 \mathrm{~mm}$ from the wall). The temperature of the flue gas was $390-450{ }^{\circ} \mathrm{C}$ before the superheaters (measured with one thermocouple situated $500 \mathrm{~mm}$ from the wall). The pressure drop over the bed was $7.0 \mathrm{kPa}$. An estimation of the fluidization velocity was carried out based on the load, heating value of the fuel, excess air ratio, furnace cross-section area, and furnace top temperature. The fluidization velocity was found to be $6.8 \mathrm{~m} / \mathrm{s}$. The furnace has a height of $13.8 \mathrm{~m}$, which results in a residence time of about $2 \mathrm{~s}$ for the flue gas and small particles in the hightemperature region. The boiler was fired with forestry residues, which means that the fuel composition differs somewhat depending upon the source and the weather conditions. An approximate analysis is given in Table 1 . The bed sand was a natural sand called Baskarpsand, with an $\mathrm{SiO}_{2}$ content of $91 \%$. Other elements given as oxides are $\mathrm{Al}_{2} \mathrm{O}_{3}, 5 \% ; \mathrm{Fe}_{2} \mathrm{O}_{3}, 0.37 \% ; \mathrm{CaO}, 0.34 \% ; \mathrm{MgO}, 0.06 \%$; $\mathrm{Na}_{2} \mathrm{O}, 1.2 \%$; and $\mathrm{K}_{2} \mathrm{O}, 2.2 \%$.

The kaolin applied here was a fine powder (36\% of the particles $<1 \mu \mathrm{m}$ and $55 \%$ of the particles $<2 \mu \mathrm{m}$ ) manufactured for the paper industry by Imerys Minerals Ltd. under the product name Intrafill $\mathrm{C}$.

General Procedure. The major events of the measurement campaign are listed in Table 2. The CFB was shutdown, cleaned, and restarted on day 0 . On day 68 , a continuous addition of $43 \mathrm{~kg}$ 
Table 2. Events of the Measurement Campaign

\begin{tabular}{ll}
\hline day & \multicolumn{1}{c}{ event } \\
\hline-2 & shutdown and cleaning \\
0 & start \\
$0-68$ & sampling without kaolin addition \\
69 & kaolin addition starts \\
$69-85$ & sampling with kaolin addition \\
85 & shutdown
\end{tabular}

of kaolin/h through the lime supply system to the particle seal was started. This corresponds to a stoichiometric ratio of kaolinite and potassium equal to 1 . The kaolin addition was applied until day 84 when the plant was shut down again. Ash samples were regularly collected during the whole period. Bottom ash amples were collected from the particle seal and the bed, and fly ash was collected from the electrofilter.

Analytical Methods. Ash samples were analyzed for chemical elemental composition, concentrations of water-soluble alkali metal compounds, and qualitative mineralogical composition. The sintering temperatures were established for particle seal samples.

The contents of major elements in the ash samples were determined by inductively coupled plasma (ICP) after melting with lithium borate and dissolution in acid. The contents of minor and trace metals were determined by ICP after dissolution in a mixture of acids in a closed Teflon bomb to prevent evaporation. The potassium content was specifically determined by both methods because potassium salts are volatile at the temperature used when melting with lithium borate. The results for potassium were most often similar, but in some cases, the content obtained after bomb dissolution was higher than those obtained after melting. In those cases, the highest content was used. The chlorine content was determined by X-ray fluorescence spectrometry (XRF).

The amount of water-soluble potassium, chloride, and sulfate was determined by extracting these ions from the sample with hot ultrapure water. The appropriate ratio of water to sample mass was 200 based on results from preliminary tests. The mixture was held at the boiling point for $5 \mathrm{~min}$ and then filtered through a membrane filter with a pore size of $0.45 \mu \mathrm{m}$. The filtrate was analyzed for potassium with atomic absorption spectroscopy (AAS) and for chloride and sulfate ions using ion chromatography. The ratio of the amount of water-soluble potassium to the total amount of potassium present in the sample was calculated. Corresponding calculations for chloride and sulfate were also performed.

The mineralogical composition of ashes was determined qualitatively by X-ray powder diffraction (XRD). Only crystalline species can be detected by this method, and the detection limit is $1-3 \mathrm{wt}$ $\%$. The instrument used is a Siemens D5000, and the identification of components was carried out using the analysis software DIFRAC AT together with the Joint Committee for Powder Diffraction Standards database.

Sintering temperatures of bed samples were established by heat treatment of the samples in an electrically heated lab-scale fluidized bed. The bed temperature is increased until bed agglomeration occurs, which is indicated by a pressure drop. The highest measurable temperature is $1100{ }^{\circ} \mathrm{C}$.

Bed particles were studied using scanning electron microscopy coupled with X-ray fluorescence spectrometry by an energydispersive detector (SEM-EDX). The electron microscope used was an Electro-scan 2020 equipment linked to an eXI EDX system. The magnification was between 300 and 1000 times. The particles were mounted in epoxy, cut, and polished to show the particle interior and the surface ash layer if present. The element-specific $\mathrm{X}$-ray fluorescence emitted was recorded as element maps by scanning the sample surface with the XRF detector.

Dilution Effects of Kaolin on Fly Ash Composition. As is shown in this paper, kaolin to a major part ends up in the electrostatic filter and thereby dilutes the fly ash. Therefore, the mass fractions from the elemental analysis cannot be interpreted straightforward. A mass balance for aluminum over the electrostatic filter can be established

$$
K A l_{K}+F A l_{F}=(F+K) A l_{F+K}
$$

where $K$ is the flow of kaolin, $F$ is the flow of fly ash, and $A l$ is the concentration of aluminum in kaolin, fly ash, or the sum of these, as denoted by indices. Because $F$ is the only unknown parameter, it can be determined. The measured concentration of an element, $X$, in the material from the electrostatic filter is $X /(F$ $+K)$. Because we are interested in $X / F$, the measured concentration is multiplied by the dilution factor $(F+K) / F$. $F$ was established as $41 \mathrm{~kg} / \mathrm{h}$, and $K$ is $43 \mathrm{~kg} / \mathrm{h}$, which means that the dilution factor is approximately 2 .

\section{Results}

The flows of ash from the furnace as bottom ash and from the electrofilter as fly ash were not measured directly. However, because the flow of fly ash was estimated to be $41 \mathrm{~kg} / \mathrm{h}$, it can be assumed that, during steady-state operation, the rest of the inflow of ash is removed as bottom ash. The inflow of ash, on the basis of the load and fuel heating value, is approximately $160 \mathrm{~kg} / \mathrm{h}$. Hence, the outflow of bottom ash is about $120 \mathrm{~kg} / \mathrm{h}$. It can therefore be concluded that the fly ash flow, although it constitutes a minor part of the total ash flow, is significant.

Table 3 shows elemental compositions of the ash samples collected in the bed, the particle seal, and the electrofilter at different dates. In the bottom ash, i.e., the bed and particle seal samples, the content of potassium decreases from around 60000 to $40000-50000 \mathrm{mg} / \mathrm{kg}$ when kaolin is added. Sodium contents are lower, but the trend is similar to that of potassium. The results for aluminum show a larger spread and no clear trend depending upon kaolin addition. The calcium content in the bed samples does not show any clear change as a result of kaolin addition either, but the calcium content in the particle seal samples decreases. The chlorine contents in these samples are below the detection level. The sulfur fractions are low as well, but there is a tendency that the content of sulfur increases as kaolin is added.

The fly ash potassium and sodium contents are both doubled, and the aluminum content increases by almost 3 times when kaolin is added. The calcium content increases significantly as well, whereas the chlorine and sulfur contents are unaffected.

Table 4 shows the contents of water-soluble potassium, chloride, and sulfate in solid samples. In addition, the soluble fraction of each element of the total mass of that element in the sample is shown. The content of soluble potassium in the bed is not clearly affected by kaolin addition, but in the particle seal, the soluble potassium increases. Here, the fraction of soluble potassium is between 1 and $2.4 \%$ and increases upon kaolin addition. The content of chloride is below the detection limit in all samples from the bed and the particle seal (bottom ash). The effect of kaolin addition on the content of soluble sulfate in these samples is somewhat unclear. The fraction of soluble sulfate from the particle seal decreases upon kaolin addition.

The fly ash contains $25000-27000 \mathrm{mg} / \mathrm{kg}$ soluble potassium, which corresponds to $45-47 \%$ of the total amount of potassium. During kaolin addition, these values decrease to 8000-12 000 $\mathrm{mg} / \mathrm{kg}$ and $13-21 \%$, respectively. The content of soluble chloride before kaolin addition in the fly ash is 7500-8900 mg/ $\mathrm{kg}$, which is $54-68 \%$ of the total chlorine. The corresponding values during kaolin addition vary, and no clear trend can be seen. The content of soluble sulfate in fly ash before kaolin addition is $45000-49000 \mathrm{mg} / \mathrm{kg}$, i.e., $69-79 \%$ of the total sulfur. This fraction seems to be unaffected by kaolin addition.

Table 5 shows the crystalline components found in the XRD analysis of samples before and after kaolin addition. The bed 
Table 3. Composition in $\mathrm{mg} / \mathrm{kg}$ of $\mathrm{K}, \mathrm{Na}, \mathrm{Al}, \mathrm{Ca}, \mathrm{Cl}$, and $\mathrm{S}$ on a Dry and Combustible Free Basis ${ }^{a}$

\begin{tabular}{|c|c|c|c|c|c|c|}
\hline sample day & K & $\mathrm{Na}$ & $\mathrm{Al}$ & $\mathrm{Ca}$ & $\mathrm{Cl}$ & S \\
\hline \multicolumn{7}{|c|}{ Bed } \\
\hline 48 & 57700 & 13100 & 36500 & 65500 & $<1000$ & 862 \\
\hline 62 & 60100 & 13300 & 38800 & 65500 & $<1000$ & 895 \\
\hline 73 & 44200 & 7210 & 27700 & 71000 & $<1000$ & 1360 \\
\hline 78 & 41800 & 12800 & 43900 & 48100 & $<1000$ & 839 \\
\hline 84 & 47500 & 8240 & 31100 & 71500 & $<1000$ & 1780 \\
\hline 85 & 47100 & 7570 & 32400 & 62500 & $<1000$ & 1520 \\
\hline \multicolumn{7}{|c|}{ Particle Seal } \\
\hline 48 & 60700 & 8460 & 24900 & 91500 & $<1000$ & 1540 \\
\hline 62 & 68000 & 8460 & 23700 & 116500 & $<1000$ & 1900 \\
\hline 73 & 43400 & 5880 & 27300 & 75000 & $<1000$ & 1850 \\
\hline 78 & 44000 & 5620 & 24000 & 80800 & $<1000$ & 1960 \\
\hline 84 & 46700 & 5850 & 28300 & 79. & $<1000$ & 2160 \\
\hline 85 & 51600 & 6110 & 36600 & 91500 & $<1000$ & 245 \\
\hline \multicolumn{7}{|c|}{ Fly Ash } \\
\hline 48 & 55300 & 9500 & 23300 & 216600 & 13000 & 21900 \\
\hline 62 & 57100 & 9200 & 21300 & 217300 & 14000 & 20700 \\
\hline 73 & $119600^{b}$ & $18700^{b}$ & 63000 & $278800^{b}$ & $12000^{b}$ & $21800^{b}$ \\
\hline 78 & $117800^{b}$ & $19000^{b}$ & 55600 & $305800^{b}$ & $14000^{b}$ & $24200^{b}$ \\
\hline 84 & $119800^{b}$ & $17800^{b}$ & 54500 & $323000^{b}$ & $16000^{b}$ & $28200^{b}$ \\
\hline 85 & $128600^{b}$ & $17660^{b}$ & 60900 & $258800^{b}$ & $12000^{b}$ & $19740^{b}$ \\
\hline
\end{tabular}

${ }^{a}$ The italic fields refer to samples taken during kaolin addition. ${ }^{b}$ The value has been adjusted with respect to dilution from kaolin as described in section 2 .

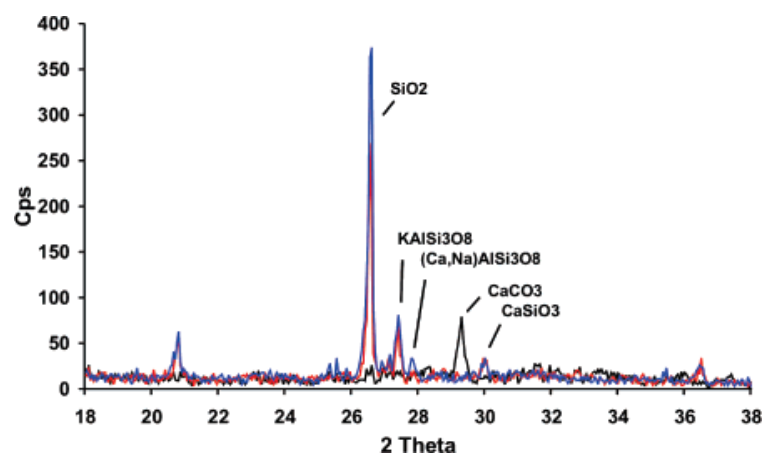

Figure 2. Major mineral components present in the different ash flows from the boiler when no addition of kaolin was applied (day 48). The blue curve represents the bed ash; the red curve represents the sample from the particle seal; and the black curve represents the fly ash.

and particle seal samples (i.e., the bottom ash) are mineralogically similar. Quartz $\left(\mathrm{SiO}_{2}\right)$ as well as the feldspars $\mathrm{KAlSi}_{3} \mathrm{O}_{8}$ and $(\mathrm{Ca}, \mathrm{Na}) \mathrm{AlSi}_{3} \mathrm{O}_{8}$ occur as natural components of the bed sand. The calcium silicate $\left(\mathrm{CaSiO}_{3}\right)$ is a product of the reaction between $\mathrm{SiO}_{2}$ and $\mathrm{CaO} / \mathrm{CaSO}_{4}$ in the fuel ash. ${ }^{27}$ Larger amounts of gehlenite $\left(\mathrm{Ca}_{2} \mathrm{Al}_{2} \mathrm{SiO}_{7}\right)$ are present in samples from the later part of the period than in the beginning. Gehlenite can be formed by the reaction between kaolin and $\mathrm{CaO} / \mathrm{CaCO}_{3} .{ }^{28}$

The fly ash contains a significant fraction of noncrystalline material or compounds that are present in very small crystallites. These components do not give a good response in the XRD analysis and can thus not be identified. The main component is calcium carbonate, but a number of other compounds were also found. There are indications that the amount of $\mathrm{CaSO}_{4}$ in the filter ash increases upon kaolin addition.

Figures 2 and 3 quantitatively show the mineral composition of ash samples before and after kaolin addition, respectively. The main differences are that the amount of $\mathrm{KAlSi}_{3} \mathrm{O}_{8}$ in the material sampled in the particle seal has increased significantly

(27) Matsuya, S.; Yamane, M. Gypsum Lime 1981, 174, 188-193

(28) Shoaib, M. M.; Amer, A. A.; El-Didamony, H.; El-Sheikh, A. A H. Silic. Ind. 2000, 65, 95-100.

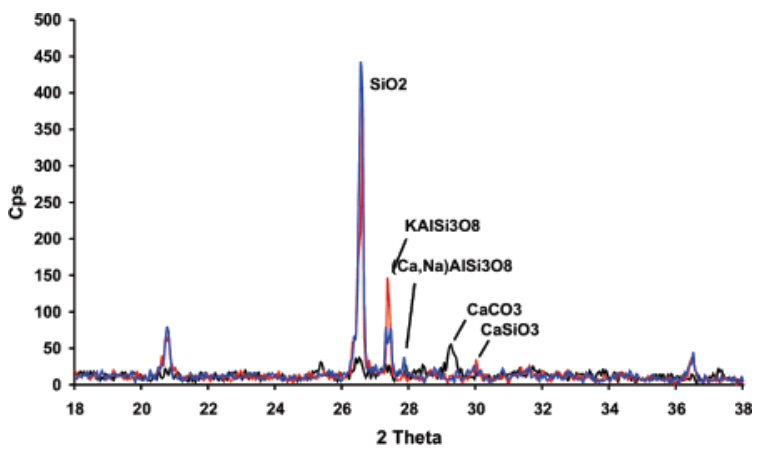

Figure 3. Major mineral components of ash sample materials late in the kaolin addition period (day 84). The blue curve represents the bed ash; the red curve represents the sample from the particle seal; and the black curve represents the fly ash.

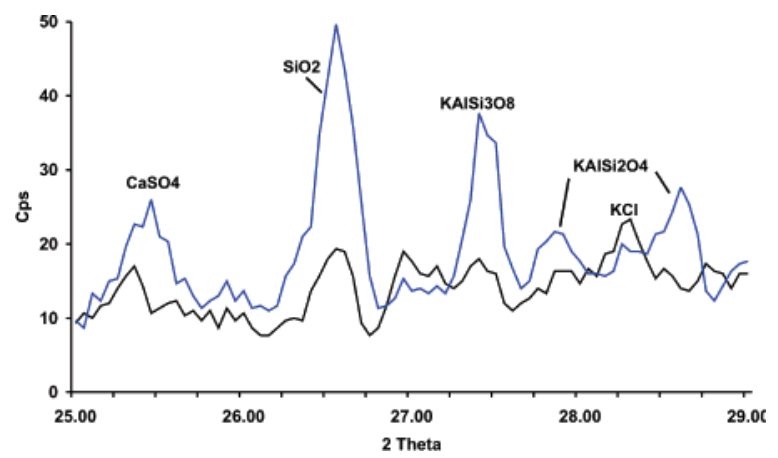

Figure 4. XRD results for fly ash samples from before the kaolin addition (black trace) and from the kaolin addition period (blue trace) showing the presence of $\mathrm{KAlSiO}_{4}$ after kaolin was added to the boiler.

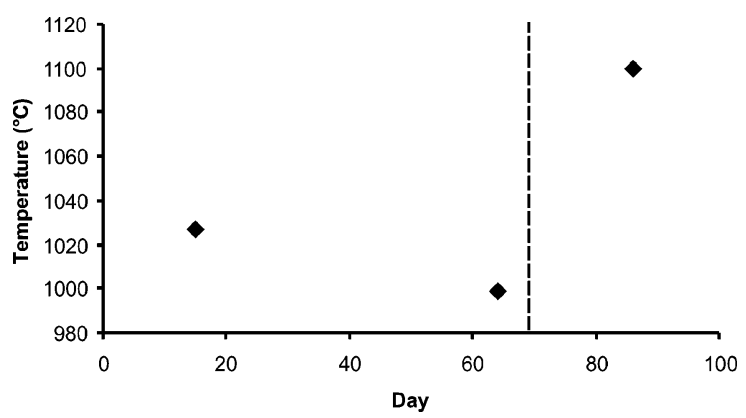

Figure 5. Sintering temperature of particle seal samples versus the day of collection. The dashed line indicates the start of the addition of kaolin.

during the kaolin addition and that small amounts of $\mathrm{KAlSiO}_{4}$ could be identified in the fly ash sampled during the kaolin period.

Figure 4 shows the mineral composition of fly ash samples. $\mathrm{KAlSiO}_{4}$ is present, and the filter ash components are either amorphous or present in very small crystallites, because the overall X-ray diffraction patterns are so weak and diffuse. However, a closer study revealed the presence of a number of compounds, many of which are calcium-based (Table 5).

Figure 5 shows the sintering temperatures observed for particle seal material sampled on three occasions. During the period when no kaolin was added, the sintering temperature decreased from 1027 to $999^{\circ} \mathrm{C}$. After about 2.5 weeks of kaolin addition, the sintering temperature has increased to $>1100{ }^{\circ} \mathrm{C}$. No sintering was actually observed when testing this sample because $1100{ }^{\circ} \mathrm{C}$ is the upper technical limit of the experimental setup.

Figure 6 shows a SEM photograph of the cross-section of a bed particle before kaolin addition. The outer part of the particle 


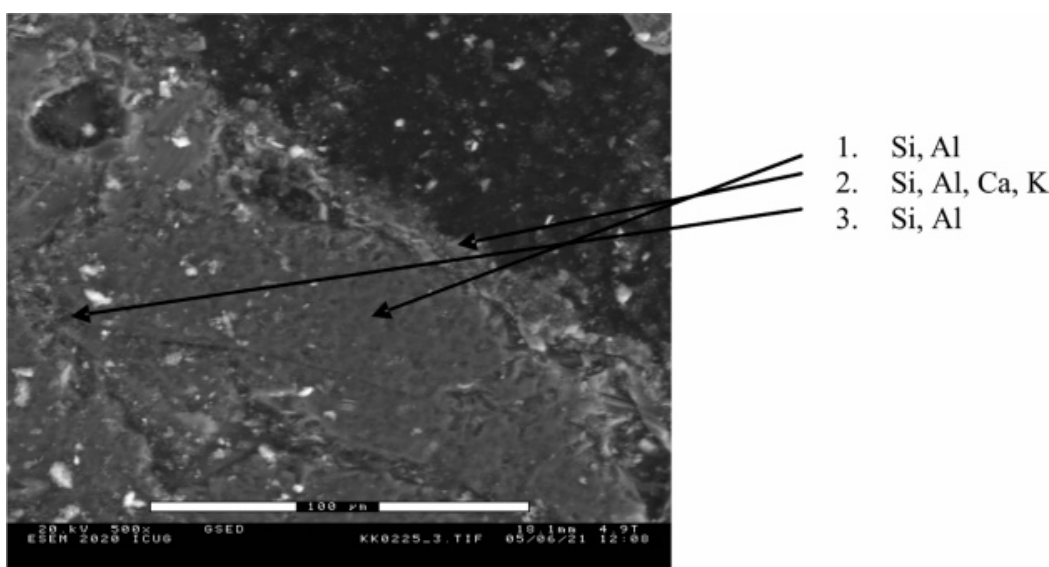

Figure 6. SEM photograph of a bed material particle before kaolin addition. The size bar in the photograph corresponds to $100 \mu \mathrm{m}$. Some elements present in three spots are indicated.

Table 4. Water-Soluble Potassium, Chloride, and Sulfate in the Samples ${ }^{a}$

\begin{tabular}{|c|c|c|c|c|c|c|}
\hline sample day & $\begin{array}{l}\text { soluble potassium } \\
(\mathrm{mg} / \mathrm{kg})\end{array}$ & $\begin{array}{l}\text { soluble fraction } \\
\text { of total potassium } \\
\text { (wt \%) }\end{array}$ & $\begin{array}{l}\text { soluble chloride } \\
(\mathrm{mg} / \mathrm{kg})\end{array}$ & $\begin{array}{l}\text { soluble fraction } \\
\text { of total chloride } \\
\text { (wt \%) }\end{array}$ & $\begin{array}{l}\text { soluble sulfate } \\
\quad(\mathrm{mg} / \mathrm{kg})\end{array}$ & $\begin{array}{l}\text { soluble fraction } \\
\text { of total sulfur } \\
\text { (wt \%) }\end{array}$ \\
\hline \multicolumn{7}{|c|}{ Bed } \\
\hline 48 & 441 & 0.77 & $b$ & & 619 & 23.9 \\
\hline 62 & 724 & 1.26 & $b$ & & 615 & 22.9 \\
\hline 73 & 284 & 0.64 & $b$ & & 911 & 22.3 \\
\hline 78 & 497 & 1.24 & $b$ & & 625 & 24.8 \\
\hline 84 & 835 & 1.89 & $b$ & & 615 & 11.5 \\
\hline 85 & 638 & 1.32 & $b$ & & 1880 & 41.2 \\
\hline \multicolumn{7}{|c|}{ Particle Seal } \\
\hline 48 & 636 & 1.04 & $b$ & & 800 & 17.3 \\
\hline 62 & 716 & 1.15 & $b$ & & 2170 & 38.1 \\
\hline 73 & 735 & 1.67 & $b$ & & 616 & 11.1 \\
\hline 78 & 740 & 1.80 & $b$ & & 739 & 12.6 \\
\hline 84 & 1140 & 2.42 & $b$ & & 789 & 12.2 \\
\hline 85 & 1150 & 2.21 & $b$ & & 810 & 11.0 \\
\hline \multicolumn{7}{|c|}{ Fly Ash } \\
\hline 48 & 25900 & 45.1 & 8870 & 68.2 & 45700 & 69.5 \\
\hline 62 & 27500 & 47.5 & 7560 & 54.0 & 48600 & 78.3 \\
\hline 73 & $19400^{c}$ & 15.9 & $11700^{c}$ & 97.1 & $49100^{c}$ & 75.1 \\
\hline 78 & $23200^{c}$ & 20.6 & $6700^{c}$ & 47.9 & $58600^{c}$ & 80.6 \\
\hline 84 & $24500^{\circ}$ & 20.0 & $12800^{c}$ & 80.2 & $63100^{c}$ & 74.6 \\
\hline 85 & $16900^{c}$ & 13.2 & $6990^{c}$ & 58.2 & $39800^{c}$ & 67.2 \\
\hline
\end{tabular}

${ }^{a}$ The italic fields refer to samples taken during kaolin addition. ${ }^{b}$ Below the detection limit. ${ }^{c}$ The value has been adjusted with respect to dilution from kaolin as described in section 2.

Table 5. Crystalline Components Found in XRD Analysis of Samples from Different Dates ${ }^{a}$

\begin{tabular}{|c|c|c|c|}
\hline day & bed & particle seal & fly ash \\
\hline 48 & $\begin{array}{l}\mathrm{SiO}_{2} \text { (quartz) } \\
\mathrm{KAlSi}_{3} \mathrm{O}_{8} \text { (potassium } \\
\text { feldspar microline) } \\
\text { (Ca,Na) } \mathrm{AlSi}_{3} \mathrm{O}_{8} \text { (calcium, } \\
\text { sodium feldspar in the } \\
\text { anorthite-albite series) } \\
\mathrm{CaSiO}_{3} \\
\mathrm{Ca}_{2} \mathrm{Al}_{2} \mathrm{SiO}_{7} \text { (gehlenite) }\end{array}$ & $\begin{array}{l}\mathrm{SiO}_{2} \\
\mathrm{KAlSi}_{3} \mathrm{O}_{8} \\
\text { traces of }(\mathrm{Ca}, \mathrm{Na}) \mathrm{AlSi}_{3} \mathrm{O}_{8} \\
\mathrm{CaSiO}_{3}\end{array}$ & $\begin{array}{l}\mathrm{SiO}_{2} \\
\mathrm{KAlSi}_{3} \mathrm{O}_{8} \\
\mathrm{CaCO}_{3} \\
\mathrm{CaO} \\
\mathrm{CaSO}_{4} \\
\mathrm{Ca}_{2} \mathrm{Al}_{2} \mathrm{SiO}_{7} \\
\text { traces of } \mathrm{KCl} \text { and } \mathrm{K}_{2} \mathrm{SO}_{4}\end{array}$ \\
\hline 78,84, and 85 & $\begin{array}{l}\mathrm{SiO}_{2} \\
\mathrm{KAlSi}_{3} \mathrm{O}_{8} \\
(\mathrm{Ca}, \mathrm{Na}) \mathrm{AlSi}_{3} \mathrm{O}_{8} \\
\mathrm{CaSiO}_{3} \\
\mathrm{Ca}_{2} \mathrm{Al}_{2} \mathrm{SiO}_{7}\end{array}$ & $\begin{array}{l}\mathrm{SiO}_{2} \\
\mathrm{KAlSi}_{3} \mathrm{O}_{8} \text { more than } \\
\text { before kaolin addition } \\
\mathrm{CaSiO}_{3} \\
\mathrm{Ca}_{2} \mathrm{Al}_{2} \mathrm{SiO}_{7}\end{array}$ & $\begin{array}{l}\mathrm{SiO}_{2} \\
\mathrm{KAlSi}_{3} \mathrm{O}_{8} \\
\mathrm{KAlSiO}_{4} \text { (small amount) } \\
\mathrm{CaCO}_{3} \\
\mathrm{CaO} \\
\mathrm{CaSO}_{4} \\
\mathrm{Ca}_{2} \mathrm{Al}_{2} \mathrm{SiO}_{7} \\
\text { traces of } \mathrm{KCl} \text { and } \mathrm{K}_{2} \mathrm{SO}_{4}\end{array}$ \\
\hline
\end{tabular}

${ }^{a}$ The italic fields refer to samples taken during the addition of kaolin. These samples contain the same components, in slightly varying amounts.

consists of an approximately $10 \mu \mathrm{m}$ thick porous layer, which according to the EDX analysis consists of silicon, aluminum, calcium, and potassium. The inner part of the particle is denser and consists of silicon and aluminum. In Figure 7, the same particle is shown together with the element maps obtained with EDX analysis over the surface. It shows that potassium and calcium are concentrated in the surface layer and that silicon and aluminum are concentrated in the inner part of the particle. 


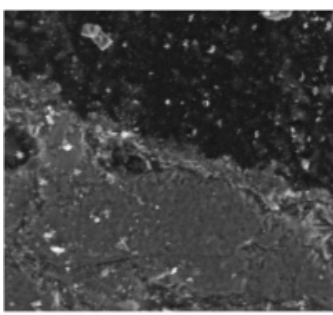

Particle cross section

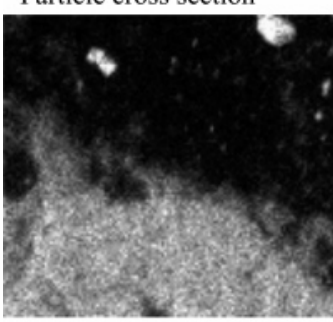

$\mathrm{Si}$

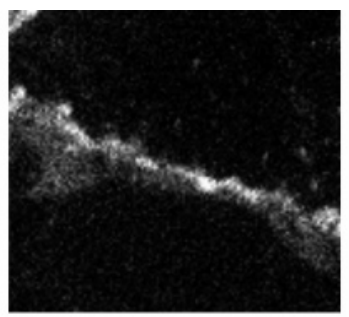

$\mathrm{Ca}$

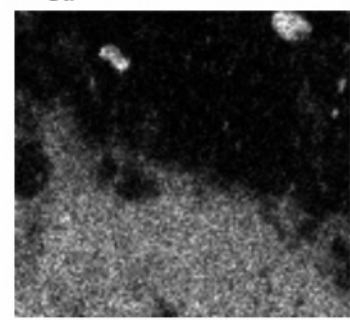

$\mathrm{Al}$

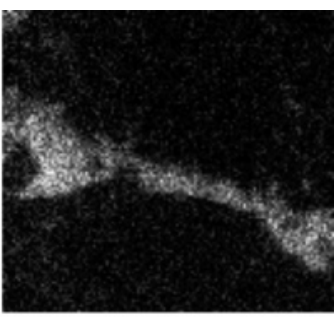

$\mathrm{K}$

Figure 7. SEM photograph and EDX mapping results for a bed particle (the same as in Figure 6) before kaolin addition. Distributions of calcium, potassium, silicon, and aluminum are shown. The surface shown in the photographs is about $160 \times 130 \mu \mathrm{m}$.

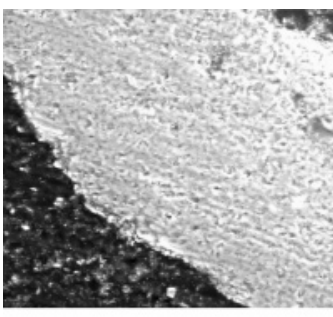

Particle cross section

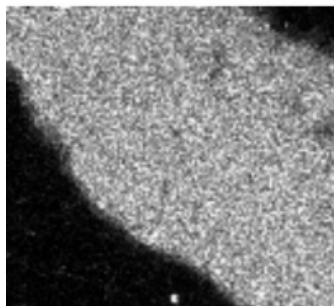

$\mathrm{Si}$

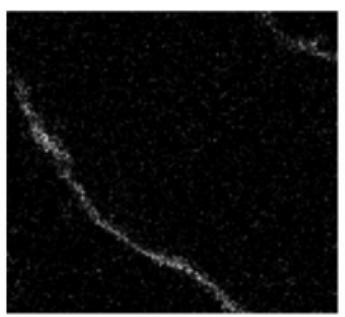

$\mathrm{Ca}$

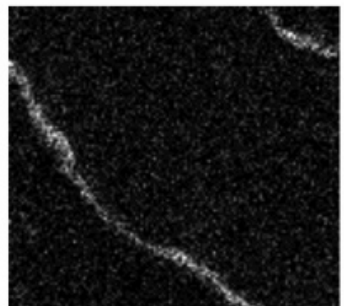

$\mathrm{Al}$

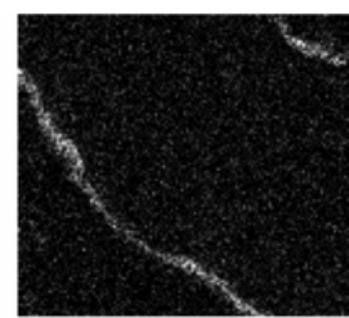

$\mathrm{K}$

Figure 8. SEM-EDX picture of a bed particle from the beginning of kaolin addition (day 73). Distributions of calcium, potassium, silicon, and aluminum are shown. The surface shown in the photographs is about $160 \times 130 \mu \mathrm{m}$.

This particle is a feldspar sand particle as shown by its content of aluminum. The bed material used in the present boiler is natural sand consisting of both quartz $\left(\mathrm{SiO}_{2}\right)$ and different feldspar minerals, such as $\mathrm{KAlSi}_{3} \mathrm{O}_{8}$, which explains the presence of aluminum in the sand particle interior.

Figure 8 shows a cross-sectioned particle from the bed taken in the beginning of the kaolin addition period (day 73). The particle has a distinct surface layer containing aluminum in addition to calcium and potassium. The particle shown in Figure 8 consists of pure quartz without feldspar. Analyses of several bed particles showed that there is no significant difference between the formation of surface ash layers on quartz and feldspar, respectively. Often, the part of the layer that is closest to the mineral surface is enriched in potassium but not so much in calcium. The outer parts of the layer contain more calcium along with potassium. The inner, potassium-rich layer is also denser than the outer, calcium-rich layer.

Figure 9 shows bed particles from the end of the kaolin addition period and elemental distribution over the particle crosssection. Similar to the particle in Figures 3 and 4, these particles exhibit an outer layer consisting of mainly calcium and potassium but also silicon and aluminum. The layer is thicker than before kaolin addition by 1.5-2 times. The inner part of the two leftmost particles consists of silicon and aluminum. The inner part of the rightmost particle consists of potassium, silicon, and aluminum, which is due to the high content of feldspar.

\section{Discussion}

Because kaolin mainly consists of kaolinite, $\mathrm{Al}_{2} \mathrm{Si}_{2} \mathrm{O}_{5}(\mathrm{OH})_{4}$, the presence of aluminum can be regarded as a sign of the presence of kaolin or reaction products thereof. The kaolin is supplied to the particle seal and must therefore pass the furnace before it enters the cyclone. The chemical analyses of bed and particle seal samples (bottom ash) did not show increased aluminum concentrations upon kaolin addition, whereas the aluminum concentration in the fly ash increased by $2-3$ times. Therefore, it is likely that the kaolin is immediately carried away by the flue gas when it enters the furnace and separated in the cyclone. The reason for this behavior is the small particle size of the kaolin. The retention time in the furnace then becomes only a few seconds. Even so, SEM-EDX analysis showed the 


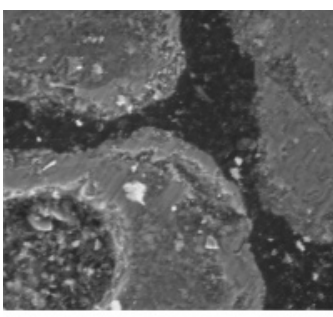

Particle cross section

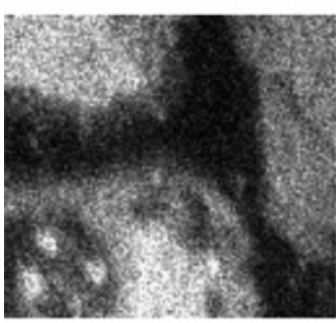

$\mathrm{Si}$

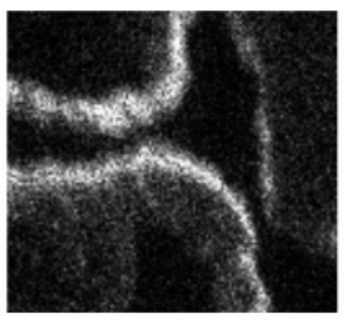

$\mathrm{Ca}$

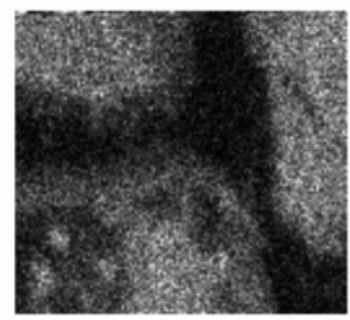

$\mathrm{Al}$

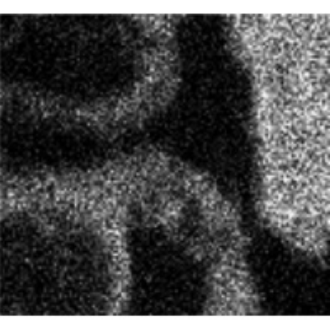

K

Figure 9. SEM-EDX picture of a bed particle at the end of the kaolin addition period (day 84). Distributions of calcium, potassium, silicon, and aluminum are shown. The surface shown in the photographs is about $160 \times 130 \mu \mathrm{m}$.

presence of aluminum in the ash layer on bed particle surfaces (Figure 8). This aluminum constitutes only a minor part of the aluminum input from kaolin. The XRD results showed no major difference between bed samples before or after kaolin addition. However, as a result of the reaction between potassium and kaolinite, the amount of $\mathrm{KAlSi}_{3} \mathrm{O}_{8}$ in the material sampled in the particle seal increases somewhat during the kaolin addition. Figures 8 and 9 show that this causes a layer on the bed particles. It has been reported earlier that kaolin may form a coating of potassium aluminum silicate on the bed particles. ${ }^{19}$ The XRD analysis of the fly ash did not reflect the increased concentration of kaolin and its reaction products with potassium that are indicated by the elemental chemical analysis results. This is due to the fact that these reaction products are mainly noncrystalline. However, small amounts of crystalline $\mathrm{KAlSiO}_{4}$ were found in the fly ash.

The potassium content decreases significantly in the bed and particle seal (bottom ash) and increases in the fly ash when kaolin is added. This is likely because of a reaction between kaolinite and potassium compounds, e.g., $\mathrm{KCl}$ or $\mathrm{KOH}$, according to reaction 1 after the release from the fuel

$$
\begin{aligned}
\mathrm{Al}_{2} \mathrm{O}_{3} \cdot 2 \mathrm{SiO}_{2}(\mathrm{~s}) & +2 \mathrm{KCl}(\mathrm{g})+\mathrm{H}_{2} \mathrm{O} \\
(\mathrm{g}) \rightarrow \mathrm{K}_{2} \mathrm{O} \cdot \mathrm{Al}_{2} \mathrm{O}_{3} \cdot 2 \mathrm{SiO}_{2}(\mathrm{~s})+2 \mathrm{HCl}(\mathrm{g}) &
\end{aligned}
$$

In our laboratory work, reaction 1 has been shown to be effective in the temperature range of $750-950{ }^{\circ} \mathrm{C} .{ }^{23} \mathrm{KOH}$ was shown to react with kaolinite as effectively as $\mathrm{KCl}$, while $\mathrm{K}_{2} \mathrm{SO}_{4}$ reacted somewhat less effectively. Potassium carbonate has been shown to react fully with kaolin at $650{ }^{\circ} \mathrm{C}$ in a similar way and to form unsoluble products. ${ }^{29}$ In the present case, the furnace temperature is in the range of $800-880{ }^{\circ} \mathrm{C}$. Reaction 1 is therefore likely to act as a potassium remover from the furnace and thereby prevent the formation of low melting point products from potassium and the quartz in the bed sand. Gaseous potassium compounds that have not undergone the reaction with kaolinite eventually condense on ash particles in the flue gas or on superheater tubes. Here, kaolin provides an additional particle surface for condensation or adsorption. The nonsticky

(29) Formella, K.; Leonhardt, A.; Sulimma, A.; van Heek, K.-H.; Jüntgen, H. Fuel 1986, 65, 1470-1472. potassium product of reaction 1 should lead to a lower risk of deposition by impaction. ${ }^{30}$

The evidence of formation of potassium aluminum silicates is convincing when considering the fly ash. According to the XRD analysis of ash samples in the present work, the major crystalline products from the kaolin reaction with potassium were $\mathrm{KAlSi}_{3} \mathrm{O}_{8}$ and $\mathrm{KAlSiO}_{4}$. The fraction of potassium in fly ash is approximately doubled upon kaolin addition, but the concentration of soluble potassium becomes slightly lower. In contrast to the potassium salts that are common in biomass ash, the potassium containing aluminum silicates have high melting points and are not very soluble in water. Thus, the effect of kaolin addition on fly ash is a sharp increase in the total potassium content and a shift from water-soluble potassium compounds to nonsoluble compounds, among which $\mathrm{KAlSi}_{3} \mathrm{O}_{8}$ is an example.

Chlorine is not found in the bed or particle seal (bottom ash). This is in accordance with results from earlier studies. ${ }^{9}$ The chlorine is likely to appear as hydrogen chloride and alkali chlorides, both of which may be stable in gaseous form at reactor temperatures. ${ }^{7,10,31,32}$ The partitioning between hydrogen chloride and alkali chlorides can be altered by the supply of aluminum silicates, such as kaolinite. ${ }^{24}$ If $\mathrm{KCl}$ reacts according to reaction 1, chlorine would be transferred from $\mathrm{KCl}$ to $\mathrm{HCl}$, which would pass the filter. However, in the present case, the fly ash content of chlorine is not affected by the kaolin addition. This indicates that potassium to a large extent is present in another form than $\mathrm{KCl}$ in the flue gas, and this is possible because of the excess of potassium to chlorine. Table 6 shows a comparison of the molar amounts of $\mathrm{K}^{+}, \mathrm{Cl}^{-}$, and $\mathrm{SO}_{4}{ }^{2-}$ ions released from the filter ash to the water phase. There is more soluble potassium than the amount corresponding to the chloride ions present. The remaining potassium ions may have been present in the fly ash as sulfate, carbonate, or hydroxide.

The soluble content of chloride in fly ash is not clearly affected by kaolin addition and neither is the soluble fraction of total chlorine. According to the $\mathrm{XRD}$ results, $\mathrm{KCl}$ was present

(30) Baxter, L. L. Biomass Bioenergy 1993, 4, 85-102.

(31) Jenkins, B. M.; Baxter, L. L.; Miles, T. R., Jr. Fuel Process. Technol. 1998, 54, 17-46.

(32) Miles, T. R., Jr.; Baxter, L. L.; Bryers, R. W.; Jenkins, B. M.; Oden, L. L. Biomass Bioenergy 1996, 10, 125-138. 
Table 6. Theoretically Possible Concentrations of $\mathrm{KCl}$ and $\mathrm{K}_{2} \mathrm{SO}_{4}$ in Fly Ash Samples Calculated from the Amounts of Potassium, Chloride, and Sulfate Ions Found in the Water Phase ${ }^{a}$

\begin{tabular}{ccc}
\hline $\begin{array}{c}\text { fly ash } \\
\text { sample day }\end{array}$ & $\begin{array}{c}\mathrm{mg} \text { of } \mathrm{KCl} / \\
\mathrm{kg} \text { of dry ash }\end{array}$ & $\begin{array}{c}\mathrm{mg} \text { of } \mathrm{K}_{2} \mathrm{SO}_{4} / \\
\mathrm{kg} \text { of dry ash }\end{array}$ \\
\hline 48 & 18600 & 35800 \\
62 & 15900 & 42600 \\
73 & 12300 & 7250 \\
78 & 7050 & 17600 \\
84 & 13500 & 11500 \\
85 & 7340 & 10300
\end{tabular}

a After calculation of the $\mathrm{KCl}$ amount, the remaining potassium was assumed to be present in sulfate form.

in small amounts in all fly ash samples. This means that the present kaolin addition was not sufficient to substantially convert $\mathrm{KCl}$ to potassium aluminum silicates. It rather seems that the $\mathrm{KCl}$ already formed remains as such when the kaolin is supplied and that the kaolin to a major part reacts with other potassium compounds.

Sulfur is found in the bed and particle seal (bottom ash) in minor amounts. $\mathrm{CaSO}_{4}$ is a likely form of sulfur, but $\mathrm{K}_{2} \mathrm{SO}_{4}$ may also be present. When kaolin reacts with potassium, more sulfur may be available to react with $\mathrm{CaO}$ to form $\mathrm{CaSO}_{4}$. Actually, the XRD results indicated that the amount of $\mathrm{CaSO}_{4}$ in the filter ash increased upon kaolin addition. $\mathrm{CaSO}_{4}$ is more stable than $\mathrm{K}_{2} \mathrm{SO}_{4}$ at furnace temperatures, and therefore, this shift of reactions would increase the stability of the sulfur compounds, which may cause the slight increase of sulfur observed in the bed and particle seal (bottm ash) upon kaolin addition. However, this increase does not seem to be very large because the sulfur fraction of fly ash is unaffected by kaolin addition and so is the amount of soluble sulfates in fly ash. On the basis of the results for water-soluble sulfate, it is also likely that the sulfate released from these samples was originally associated with calcium rather than with potassium. The presence of $\mathrm{CaSO}_{4}$ in the anhydrite form was shown by the $\mathrm{XRD}$ results.

The total amount of calcium in the bed is not affected by the kaolin, but there is a small decrease in particle seal samples. Because some kaolin obviously ends up on bed particle surfaces, it may replace some calcium that instead is found in the fly ash. The calcium concentration increases significantly in fly ash during kaolin addition.

\section{Conclusions}

The effects of adding kaolin to the particle seal are (1) The sintering temperature of the bed material increases because of the removal of potassium and the formation of potassium aluminum silicates in the bed. These products do not form low melting eutectic mixtures with quartz, as the potassium salts may do.

(2) Kaolin captures potassium and thereby removes it from the furnace to the fly ash filter. The product is stable at combustion temperatures and less liable to deposit than other potassium compounds. Furthermore, less potassium is available for the reaction in the furnace.

(3) The addition of kaolin to a fluidized-bed boiler significantly decreases the risk for bed agglomeration and superheater deposits in large-scale biofuel combustors.

Acknowledgment. This work has been financed by Nässjö Affärsverk $\mathrm{AB}$, which is gratefully acknowledged. We also thank Erkki Ruskola and Peter Svensson (at Nässjö Affärsverk AB) for support. The technical contributions by Magda Wilewska-Bien and Karin Karlfeldt in performing some of the analytical work are gratefully recognized.

EF070055N 